The 49th Annual Conference of the International Association of School Librarianship

The 24th International Forum on Research on School Librarianship

July $12-16,2021$

Barbara Schultz-Jones, Marcia Mardis, Sue Kimmel

University of North Texas, Florida State University, Old Dominion University

\title{
After CLASS: What's Next for School Library Research
}

\section{Abstract}

The research process of the CLASS II research agenda is detailed along with findings from the formal final report of the project. Findings are organized by using the shared foundations from the 2017 AASL National School Library Standards and include highlights from the aggregated research. A discussion of innovative future directions for school library research builds on the CLASS II research findings.

Keywords: CLASS II, research, school library, future, conjecture maps

\section{Introduction}

In 2014 the American Association of School Librarians (AASL) initiated a research agenda called Causality School Librarians and Student Success, or CLASS. In the initial phase, fifty researchers were convened to discuss the need and approach for school library research which culminated in a white paper that laid out a ten-year research agenda for AASL (see Figure 1).

Figure 1

CLASS Research Agenda (AASL, 2014)

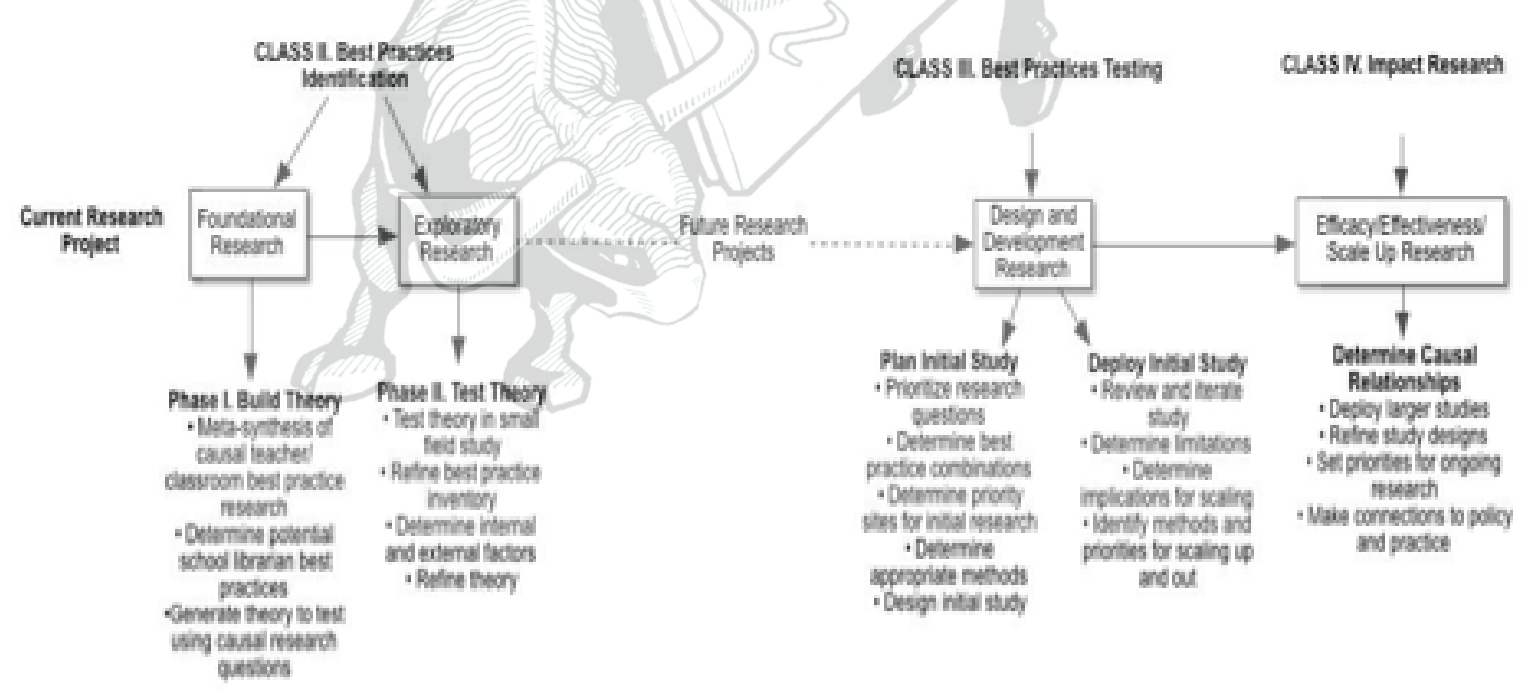

The second phase of this research agenda (CLASS II) tasked three research teams with the research question: "What causal relationships between school-based malleable factors and 
student learning are present in published research?" The research teams from Florida State University, Old Dominion University and the University of North Texas conducted a large-scale meta synthesis of effective classroom teacher practices documented by high quality causal research publications. The CLASS II research teams also extended a call for small-scale field studies. Those practices were examined alongside the synthesized findings to develop possible testable designs. Theoretical conjectures can be used to refine and understand how classroom practices translate to a school library environment. As a closing step to the CLASS II research a CLASS Summit was held at the American Library Association (ALA) 2020 midwinter conference.

\section{Statement of the Research Problem}

School library research has a strong history of correlational studies, and supporters of school libraries intuitively know that school libraries support student learning. Despite a history of groundbreaking work from Mary Gaver (1960, 1961, 1963), more than 15 state-based studies (Scholastic, 2016) suggesting a link between school libraries and student achievement, and Todd's (2006) call for evidence-based research the school library profession still struggles to disseminate results and gain recognition from administrators and lawmakers. AASL viewed a logical next step in the process of connecting school libraries to student learning as the development of a causal research corpus to demonstrate to the education community that school librarians have a potential role in developing solutions to problems such as achievement gaps, student retention, or college and career readiness.

\section{Literature review}

Correlational studies in education (e.g., Coleman, 1966) and school librarianship (e.g., Lance \& Hofschire, 2011, 2012) have surfaced numerous strong relationships that could be promising areas for causal research.

Todd $(2006,2009,2015)$ articulated evidence-based practice for school libraries and presented a holistic model that values the research to practice cycle. Todd's call to action invigorated school library research with a focus on developing the evidence for practice, evidence in practice, and evidence of practice. Todd (2015) emphasized that:

this practice forms a framework for reflective experience and understanding of the needs of our students and for judicious use of research-derived evidence to make judgments and decisions about how to enact instructional and service roles of the school library to meet the goals of the school. (p. 9)

Lyons (2009) stressed the need for school library research to move away from advocacy-driven research: "EBP requires that the effectiveness of school libraries in meeting specific student needs be evaluated in comparison with relevant alternative educational interventions" (p. 65).

With a strong focus on research to validate worth, the school library evidence base is mainly composed of descriptive, qualitative work complemented by survey reports (Johnston \& Green, 2018; Mardis, 2011; Morris \& Cahill, 2016; Neuman, 2003), leaving a wide range of 
opportunities for researchers to explore other quantitative approaches, perhaps even beginning with refined action research projects (Lyons, 2009). And, as Haycock and Stenström (2016) state: paradoxically, no sector in the library community has more evidentiary support for meeting the funder's mission than school libraries, while no sector has suffered from greater decline in support across the continent (p. 5).

Along with methodological choices, less clear are the topics on which school library researchers should focus. Aggregating and synthesizing existing causal research was a starting point for the CLASS II researchers.

\section{Methodology}

The aggregation of high-quality causal research began with 1,598 studies published between 1985-2016, collected by the three research teams using different search strategies towards a meta-analysis to answer the question: What causal relationships between school-based malleable factors and student learning are present in published research? School-based factors were defined as learning activities that occur within school, such as classroom practices, after-school programming, or other factors that might be manipulated within a school.

The Florida State team focused on research contained with the What Works Clearing House; the Old Dominion team focused on a wide search of education literature, including Hattie's (2009) collection; the University of North Texas team searched for causal studies that included school libraries. Details of the search techniques can be found in the CLASS II final report (AASL, 2021a). Once these studies were gathered, the assessment process utilized the U.S. Department of Education's highest standards for evidence as a means of evaluating the strength of the research design and findings.

The U.S. Department of Education's Every Student Succeeds Act (ESSA) is federal education legislation for primary and secondary schools. ESSA uses four levels of evidence ranging from demonstrates a rationale (with a well-specified logic model informed by research), through promising (correlational studies), then moderate and finally strong, which includes quasi experimental and experimental research. These standards reflected the priority emphasis on causal evidence in education at the time the CLASS II research began. However, during the project the U.S. Department of Education shifted its policy stance from a positivist causal paradigm to a design-based approach through research practitioner partnerships (RPPs), a shift that was compatible with many of the opportunities identified for future research. While the U.S. Department of Education returned to the positivist perspective two years later, the value of RPPs cannot be overstated.

The final 310 studies that remained, after the ESSA standards were applied, focus on the two top levels of moderate and strong research. Complementing the aggregated studies were a set of three field studies that occurred over eighteen months, between 2017 and 2018, conducted by research teams who responded to the CLASS II Request for Proposal with small-scale, design-based causal studies in a school library field context. 
Conjecture maps that extend suppositions and proposals about promising research proved to be a constructive vehicle to engage with theory. The conjecture map (see Figure 2) is a vehicle that facilitates the movement of assumptions through the research design and the mediating factors that will lead to outcomes. An important aspect of conjecture maps is their iterative nature. They are intended to evolve in an iterative sequence as design hypotheses are tested. Examples of conjecture maps were added to the final CLASS II report as a way to illustrate the potential for this approach and identify opportunities for future research.

\section{Figure 2}

The grammar of conjecture mapping (Lee, Recker, and Phillips 2018)

\section{The Grammar of Conjecture Mapping}

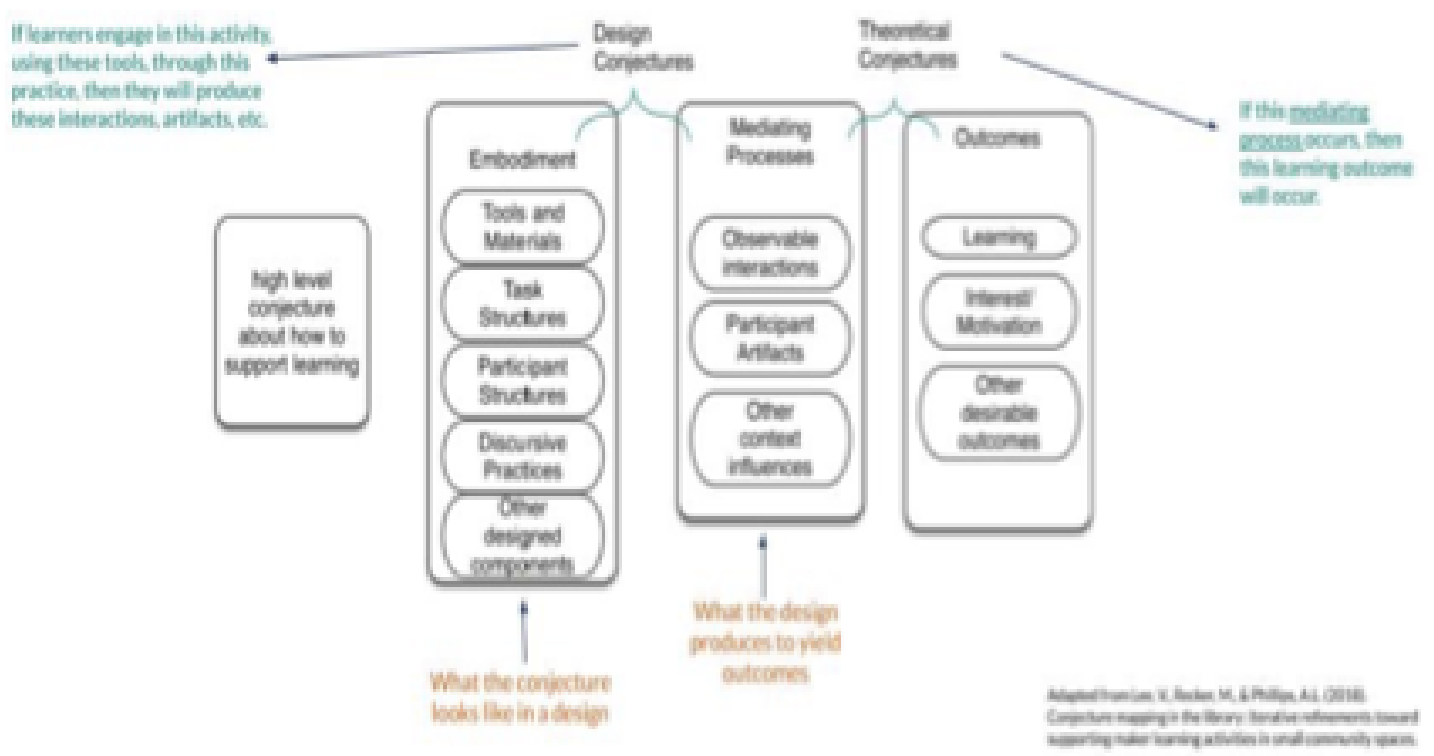

An additional step was applied following the introduction of the AASL National School Library Standards in 2017, after the CLASS II research was under way. While the analysis was not prescribed by the AASL Standards, the standards provided a constructive way to view and organize the project's research findings. As a result, the final report, in full (AASL, 2021a) and in a shortened Executive Summary form (AASL, 2021b), provides access to the findings through the shared foundations. From those 310 studies a number of effective practices were identified that school librarians could implement. Conjecture maps from several of these effective practices were developed and used to demonstrate the findings.

\section{Findings}

As with any synthesis of research findings, the need to organize and develop a schema was of primary importance. Utilizing the AASL (2017) shared foundations facilitated that organization as the themes emerged in a natural formation within that framework. As AASL asserts: the framework reflects a comprehensive approach to teaching and learning by demonstrating the 
connection between learner, school librarian, and school library standards (2021c). Accordingly, the findings are presented in association with those six shared foundations: Inquire, Include, Collaborate, Curate, Explore and Engage. Conjecture maps and leading questions are included to prompt and encourage future research. Table 1 summarizes the key areas for consideration in each of the shared foundations.

Table 1

Major areas from research syntheses (AASL,2021a), p. 4

\begin{tabular}{|c|c|c|c|}
\hline \multirow{2}{*}{$\begin{array}{c}\text { Shared } \\
\text { Foundation }\end{array}$} & \multicolumn{3}{|c|}{ Research Synthesis Area } \\
\hline & Learner & School Librarian & School Library \\
\hline Inquire & $\begin{array}{l}\text { Strengthening } \\
\text { intellectual tools }\end{array}$ & Instructional approaches & Climate \\
\hline Include & $\begin{array}{l}\text { Self-concept } \\
\text { Inclusive learning }\end{array}$ & $\begin{array}{l}\text { Learning trajectories } \\
\text { Positive perception of } \\
\text { learners } \\
\text { Individualized } \\
\text { instruction }\end{array}$ & $\begin{array}{l}\text { Opportunity to learn } \\
\text { Interdisciplinary } \\
\text { instruction }\end{array}$ \\
\hline Collaborate & $\begin{array}{l}\text { Shared learning } \\
\text { experiences }\end{array}$ & $\begin{array}{l}\text { Co-planning } \\
\text { Co-teaching } \\
\text { Professional } \\
\text { development delivery }\end{array}$ & $\begin{array}{l}\text { School-wide } \\
\text { commitment } \\
\text { Parent involvement }\end{array}$ \\
\hline Curate & $\begin{array}{l}\text { Thinking skills and } \\
\text { strategies }\end{array}$ & $\begin{array}{l}\text { Challenging learners } \\
\text { Expert curation }\end{array}$ & $\begin{array}{l}\text { School library as } \\
\text { instructional resource }\end{array}$ \\
\hline Explore & $\begin{array}{l}\text { Reading } \\
\text { Experiential learning }\end{array}$ & $\begin{array}{l}\text { STEM learning } \\
\text { opportunities } \\
\text { Technology-aided } \\
\text { instruction } \\
\text { Early intervention into } \\
\text { reading problems } \\
\text { Increasing exposure to } \\
\text { books and reading } \\
\text { Modeling reading }\end{array}$ & $\begin{array}{l}\text { Cooperative learning } \\
\text { Reading practice } \\
\text { Reading widely and } \\
\text { deeply } \\
\text { Reading beyond the } \\
\text { school day } \\
\text { Talking about reading }\end{array}$ \\
\hline
\end{tabular}




\begin{tabular}{|l|l|l|l|}
\hline Engage & Parent involvement & Connecting with field & Opportunities to lead \\
Self-perception & experts and & and communicate \\
Structured curriculum & professionals & Support for college \\
Mentoring learning & & & success \\
Adventure-based & & Same-day \\
& curricula & & configurations \\
\hline
\end{tabular}

Inquire: The skills needed to effectively power the Inquire Shared Foundation are curiosity and questioning for learners of all ages (AASL, 2018, p. 28). The research synthesized

places inquiry and investigation at the core of the learner experience. School librarians and other educators engage learners in the use of inquiry-based models, and learners benefit from guides to their inquiry processes. Learners' cognitive development processes with various subjects inform scaffolding of these processes. Instructional design, learning activities, a collaborative approach, and development of critical thinking skills are fundamental to research related to this foundation. (AASL, 2021a, p. 17)

Suggestions for research with practitioners include:

- Investigate the impact of information load on problem solving.

- To what extent do learners benefit from guides to their inquiry processes, and where are these guides best positioned for optimum results?

- To what extent does routine metacognitive conversation (talking about the reasoning and problem-solving processes that accompany reading) affect learning as learners carry out learning tasks in the school library's makerspace area (science curriculum)? (AASL, 2021a, p. 20)

Include: When learners' community includes members with diverse experiences, learners are aware of a range of viewpoints and anticipate the challenges often encountered in reaching consensus (AASL, 2018, p. 29). The research found that:

dimensions of diversity addressed in educational research include socioeconomic, racial and cultural, linguistic, and gender identities as well as individual developmental and learning differences. Often an intervention or teaching practice has different impacts for different learners, suggesting the need to consider individual differences when designing instruction. Interdisciplinary approaches to teaching and learning engage both educators and learners with multiple perspectives (AASL, 2021a, p. 33).

Suggestions for researcher-practitioner partnerships include the questions:

- Do learners in schools in lower-socioeconomic neighborhoods with increased staffing and hours (after-school, weekends, vacations, summers) perform differently on reading 
assessments than similar learners from similar neighborhoods with practice as usual (open only during school hours)?

- How do learners who receive information skills instruction integrated with disciplinary content compare with similar learners who do not receive information skills instruction integrated with content or who receive no information skills instruction on measures of information skills and measures of disciplinary content? (AASL, 2021a, p. 39)

Collaborate: Collaborative learning involves groups of learners working together to solve a problem, complete a task, or create a product (AASL, 2018, p. 29). Education research suggests: collaboration may be seen a bit differently than school librarians often consider. For example, educators may consider working with parents as collaboration. In some schools, a building-wide commitment to collaborative decision making is a form of collaboration. While collaboration is a frequently discussed and researched topic in school librarianship, it has not been the focus of many causal research studies. (AASL, 2021a, p. 41).

Questions for future research include:

- What are the features unique to school librarianship that enhance collaborative relationships? How large of a part of the successful collaborative relationship are these features?

- How and why does school librarian-educator collaboration improve learners' experiences? How do these advantages compare to educator-only instruction?

- What are the differences between collaborations with classroom teachers that include school librarians who were former teachers and collaborations with school librarians who were not? How does classroom teaching experience improve or impede successful school librarian-educator collaborations?

- In schools without a collaborative culture, how do school librarians contribute to learning? (AASL, 2021a, p. 42)

Curate: Curating resources involves the collection, organization, description, and sharing of resources to make meaning for the learner and others (AASL, 2018, p. 30). Studies in the educational research found that:

A vital component of this foundation is providing access to resources, along with the ability to evaluate and select appropriate resources for the information task. Organizing these resources, conceptually and strategically, involves assessing the authority, currency, relevancy, scope, and relationship to other items collected to satisfy an information need. What the school librarian does to curate a collection of resources for the school's information and curricular needs, is scaled to the learner's level of need to evaluate and select resources (AASL, 2021a, p. 51).

Queries related to the curate foundation include: 
- Which curation skills can the school librarian model for learners to impact learning? (AASL, 2021a, p. 52)

- Will the effect of a one-to-one laptop program impact learner learning in subjects where content-specific applications are provided by the school library?

- Will the effect of a one-to-one laptop program impact learner learning in subjects where the school librarian is included in the selection and introduction of online resources? (AASL, 2021a, p. 57)

Explore: When learners explore, they consider their existing knowledge, formulate authentic questions, experiment with physical and intellectual pursuits, collaboratively investigate answers, self-assess progress, and openly receive constructive feedback to strengthen their skills (AASL 2018, p. 30). Studies in the aggregation:

supported the use of manipulatives, real-world materials, and other hands-on explorations and models related to learning in content areas like math, science, or social studies. Reading as "the core of personal and academic competency" (AASL, 2018, p. 13) is also explicitly addressed in the Explore Shared Foundation: "Learners develop and satisfy personal curiosity by reading widely and deeply in multiple formats and write and create for a variety of purposes" and “[s]chool librarians foster learners' personal curiosity by encouraging learners to read widely and deeply..." (AASL, 2018, p. 104). A significant number of studies from educational research and identified in the CLASS aggregation concern learning to read. (AASL, 2021a, p. 61).

Queries for research and practice include:

- How do the reading activities and materials provided by professional librarians through the school and public library contribute to student learning outcomes?

- How might the practice of read-alouds by the librarian be enhanced through attention to phonemic and phonological structures, word study, and vocabulary through authentic texts?

- How do guided inquiry projects planned collaboratively with teachers and led by the school librarian contribute to learner reading skills of expository material? In particular if the projects include instruction and modeling for the extraction of relevant information from a variety of texts? If they include an authentic, outside audience? (AASL, 2021a, p. 65)

Engage: Engagement is the degree of attention, curiosity, interest, optimism, and passion that learners show when they are learning or being taught (AASL, 2018, p. 31). The education research focused on several themes:

Learner engagement has affective, attitudinal, and socio-emotional dimensions, and matters of behavior are included in this Shared Foundation. From a school librarian and school library perspective, this Shared Foundation also encompasses 
relationships with parents and community organizations, including

extracurricular, service, and informal learning. (AASL, 2021a, p. 71).

Prompts for future research include:

- Which theories explain the value of learners' engagement with the community beyond the school?

- What is the role of external engagement and awareness of the world beyond school in digital literacy teaching and learning?

- How can school counselors and school librarians work together to ensure that learners understand their post-graduation options? (AASL, 2021a, p. 65)

\section{Implications and Conclusions}

Since CLASS II was a project initiated and supported by AASL, the decisions related to what comes next ultimately lie with that organization. Recommendations to AASL included: creating a dedicated online space to increase the visibility and communication of research related to school librarians and advance ongoing research, pursuing funding of research-practitioner partnership to further exploration of the areas for research identified in the CLASS II report, and continuing to apply the shared foundations from the AASL standards to ongoing research.

As researchers currently examining the body of evidence and seeing new directions for research, we still agree with Todd's 2009 statement that there remains:

an urgency for the whole school library research community to engage in some sustained and complex discussions on the future directions of school librarianship research, and what is needed to continue building a strong research base for the profession (p. 91).

Whether these directions take the form of discussion towards a new formalized research agenda by the national association, rigorous research based on the findings from the CLASS II research, or research based on evidence in practice and the application of the new U.S. National Standards, the research base for the school librarianship profession needs continuous reflection, refreshment and a firm foundation.

As underlying themes, we can see through the aggregated research that training is necessary to implement an intervention with fidelity and flexibility. Training relates to the school librarian and also extends to the teaching faculty within a school in terms of understanding the process and implications of an intervention. Discourse is important: learners need to talk about what they are learning. Whether the discourse is internal reflection or social exchanges, talking through the process of learning and thinking about other points of view is important and effective for learning and anchoring concepts. Being focused on the curriculum and opportunities to learn makes a significant difference - school librarians can collaborate with teachers to effectively link the curriculum to school library activities.

At the basis of all themes is an understanding of how learners learn: 
The search for meaning occurs through patterning. Every human being is born with a drive to make sense of experience. Simply put, in the real world all human beings (and every living organism) have to engage with their environment as a matter of survival. Cognition is emotional. Among the many factors that influence meaning making is the fact that cognition is affected by emotions. The brain/mind is social. No one is an island, not biologically. Even for people who love to spend most time alone, some aspects of learning are intrinsically social (Caine \& Caine, 2011, p. 15).

An understanding of how learners learn extends naturally to reading. Reading was consistently identified as a key research priority and school librarians are well positioned to contribute to the development and extension of reading skills.

Further development of conjecture maps and exploration of Researcher Practitioner Partnerships (RPPs) extend the research possibilities. Conjecture maps are an effective way to test hypotheses and design research that evolves through its design and application. The emergence of consideration of the school library and its role with social justice is an area that could benefit from the use of this innovation to explicitly articulate the conjectured relations between social justice goals and the learning designs and context.

What should not be overlooked is the role of the school librarian:

School libraries, e.g., are not scarce as they continue to exist. Advocating for them is counterproductive as the room continues to exist. What is scarce is the unique expertise of the teacher-librarian and the behaviors that contribute to student learning. (Haycock \& Stenström, 2016, p. 137)

Building on the expertise of the teacher-librarian, leveraging the behaviors that contribute to student learning, and providing the evidence of practice is our forward-thinking challenge.

Acknowledgement: This research is supported in part by the American Association of School Librarians through IMLS grants RE 62-13-0212-13 and RE-00-15-0114-15.

\section{References}

American Association of School Librarians [AASL]. (2014, December). Causality: School librarians and student success (CLASS). American Association of School Librarians National Research Forum white paper. Chicago, IL: American Library Association. http://www.ala.org/aasl/sites/ala.org.aasl/files/content/advocacy/research/docs/CLAS SWhitePaper_FINAL.pdf

American Association of School Librarians [AASL]. (2018). National school library standards for learners school librarians, and school libraries. Chicago: ALA editions. https://standards.aasl.org/ 
American Association of School Librarians [AASL]. (2021a). Educational research applied to the shared foundations: A report of the CLASS II research project. https://www.ala.org/aasl/sites/ala.org.aasl/files/content/advocacy/research/docs/AASL _ClassIIResearch_Book.pdf

American Association of School Librarians [AASL]. (2021b). Educational research applied to the shared foundations: An executive summary of the CLASS II research project.

https://www.ala.org/aasl/sites/ala.org.aasl/files/content/advocacy/research/docs/AASL _ClassIIResearch_Summary-LETTER.pdf

American Association of School Librarians [AASL]. (2021c). National School Library Standards: AASL Standards Framework. https://standards.aasl.org/framework

Caine, R.N. \& Caine, G. (2011). Natural learning for a connected world: Education, technology, and the human brain. Teachers College Press.

Coleman, J.S. 1966. Equality of Educational Opportunity. Washington, D.C.: National Center for Educational Statistics.

Gaver, M. V. (1960). Effectiveness of centralized library service in elementary schools (phase 1) [mimeographed]. New Brunswick, NJ: Graduate School of Library Service, Rutgers, the State University.

Gaver, M. V. (1961). Effectiveness of centralized library service in elementary schools (phase I). Library Quarterly, 31, 254-256.

Gaver, M. V. (1963). Effectiveness of centralized library service in elementary schools. 2nd ed. New Brunswick, NJ: Rutgers University Press.

Hattie, J. (2009). Visible learning: A synthesis of over 800 meta-analyses relating to achievement. New York: Routledge.

Haycock, K. \& Stenström, C. (2016). Reviewing the research and evidence: Towards best practices for garnering support for school libraries. School Libraries Worldwide, 22(1), 127-142.

Johnston, M. P., \& Green, L. S. (2018). Still polishing the diamond: School library research over the last decade. School Library Research, 21. Retrieved February 10, 2020 from http://www.ala.org/aasl/sites/ala.org.aasl/files/content/aaslpubsandjournals/slr/vol21/S LR_StillPolishingUPDATED_v21.pdf

Lance, K. C., \& Hofschire, L. (2011). Something to shout about: New research shows that more librarians means higher reading scores. School Library Journal, 57(9), 28-33.

Lance, K. C., \& Hofschire, L. (2012). Change in School Librarian Staffing Linked with Change in CSAP Reading Performance, 2005 to 2011. Library Research Service.

Lee, V. R., Recker, M. \& Phillips, A. L. (2018). Conjecture mapping the library: Iterative refinements toward supporting maker learning activities in small community spaces. Paper presented at the Rethinking Learning in the Digital Age: Making the Learning Sciences Count 13th International Conference of the Learning Sciences London, UK. https://digitalcommons.usu.edu/itls facpub/638/. 
Lyons, R. (2009). The call for evidence based practice: Speaking louder than words. Evidence Based Library and Information Practice, 4(3), 63-67.

Mardis, M. A. (2011). Evidence or evidence based practice? An analysis of IASL Research Forum Papers, 1998-2009. Evidence Based Library and Information Practice, 6(1), 4-23.

Morris, R. J. \& Cahill, M. (2016). A study of how we study: Methodologies of school library research 2007 through July 2015. School Library Research, 20. Retrieved from https://files.eric.ed.gov/fulltext/EJ1131164.pdf

Neuman, D. (2003). Research in school library media for the next decade: Polishing the diamond. Library Trends, 51(4), 503-524.

Scholastic. (2016). School libraries work: A compendium of research supporting the effectiveness of school libraries. New York: Scholastic Library Publishing. Retrieved January 30, 2020, from http://www.scholastic.com/slw2016/

Todd, R. (2006). School libraries and evidence-based practice: An integrated approach to evidence. School Libraries Worldwide, 12(2), 31-37.

Todd, R. J. (2009). School librarianship and evidence-based practice: Progress, perspectives, and challenges. Evidence Based Library and Information Practice, 4(2), 78-82.

Todd, R. (2015). Evidence-based practice and school libraries: Interconnections of evidence, advocacy, and actions. Knowledge Quest, 43(3), 8-15.

United States. Department of Education. (2016). Non-regulatory guidance: Using evidence to strengthen education investments. Retrieved May 30, 2018, from https://www2.ed.gov/policy/elsec/leg/essa/guidanceuseseinvestment.pdf 